\title{
Loving Kindness and Mercy: their Human and Cosmic Significance*
}

\author{
JOHN COTTINGHAM
}

\begin{abstract}
This paper starts by examining the language used in some well known scriptural passages where the importance of mercy or compassion is stressed. Such passages underline the ethical importance of a direct, physically and emotionally involved response. This leads on to a critique of the shortcomings of approaches to ethics which advocate the impersonal promotion of welfare; our lives as ethical beings depend intimately on the immediate responses arising from our encounters with others in our day-to-day lives. The paper then further explores the special status of loving kindness and mercy in the Judaeo-Christian tradition, and argues that secular ethical systems, whether grounded in human nature or in the supposed requirements of rationality, are unlikely to be able to underwrite this kind of status. The final section reflects further on the 'cosmic' significance of love in a theistic worldview.
\end{abstract}

\section{The phenomenology of mercy}

Let me begin with the episode of the healing of the blind men in the Gospel of Matthew. Two blind men sitting by the wayside, heard that Jesus was passing by, and shouted out "Son of

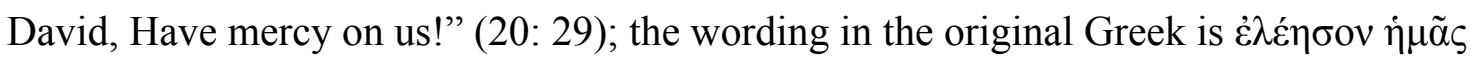
(eleēson hèmas). The Greek verb of course has familiar and very ancient religious connotations, from the Kyrie Eleison which occurs in Eastern Orthodox and Byzantine rite Christian liturgies, as well as near the start of every Catholic Mass or Anglican Eucharist. But as a translation of the plea of the blind men, 'have mercy' is perhaps not ideal: to the modern secular ear it probably suggests a judicial context, where justice or punishment is in prospect and the prisoner at the bar begs for leniency. ${ }^{1}$ On the other hand, 'Have pity on us', as some translations render it, also seems to have the wrong connotations. Pitying someone ('I pity you') somehow conveys something rather detached or aloof, like 'I'm very sorry for you' (which is actually one of the most chillingly unhelpful things to be told if you are in a

\footnotetext{
* This is a typescript of an article the definitive version of which is published in Philosophy (2018 or 2019).

${ }^{1}$ A point made by Robin Gill, Why does God allow suffering? (London: SPCK, 2015), 34.
} 
trouble). The blind men didn't want pity, they wanted help. Things are easier in Latin:

Miserere nostri (as the Vulgate translation has it) reminds us of the noun misericordia, what beggars and supplicants cry out for, and of course of the prayer miserere nobis, in the Agnus Dei: Agnus Dei, qui tollis peccata mundi, miserere nobis. ${ }^{2}$

But it is the response of Jesus to the blind men's plea, as described in Matthew, that I want to focus on. One might have expected the simple 'and he had mercy on them and opened their eyes' (which is what the Vulgate says, 'having mercy', misertus) ${ }^{3}$ but what we

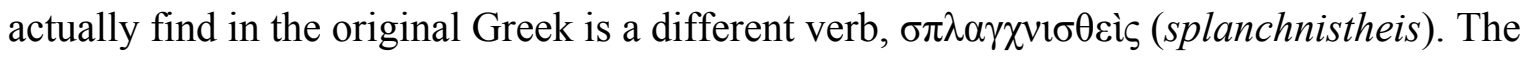
King James version has 'and Jesus had compassion on them and opened their eyes', but the American standard translation, rather better on this occasion, has 'and Jesus was moved with compassion ...' The verb used in the original, $\sigma \pi \lambda \alpha \gamma \chi v i \zeta o \mu \alpha 1$ (splanchnizomai), comes from $\tau \alpha \dot{\alpha} \sigma \pi \lambda \alpha_{\gamma} \gamma \chi \alpha \alpha$ (ta splanchna), corresponding to the Latin viscera, the bowels, the entrails. The same verb is used in Mark 1:41 (of Jesus' reaction to the leper who knelt down and implored him 'If you are willing you can make me clean'); and the cognate noun comes in Luke in the Benedictus, the Canticle of Zacharias, father of John the Baptist, when his tongue was finally loosed and he proclaimed the destiny of the child, to prepare the way of the Lord and to give knowledge of salvation to his people. The beautiful King James Version goes on: 'through the tender mercy of our God, whereby the dayspring from on high hath visited us.' The Greek

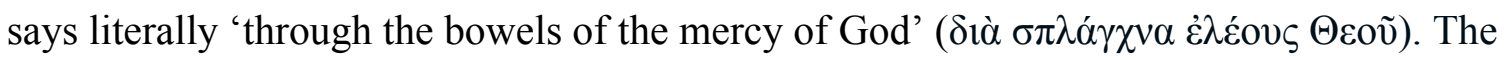
same root comes in the most famous parable in Luke, the prodigal son, where the wretched spendthrift, having lost everything, slinks back home in desperation and the father seeing him a long way off, is moved with compassion $\dot{\varepsilon} \sigma \pi \lambda \alpha \gamma \chi v i ́ \sigma \theta \eta$ (esplanchnisthe), and runs across the field to meet him and embrace him (15:20).

The very direct and physical flavour of the language matches what one finds in the Hebrew Bible, where much of the imagery (as is often remarked) is characteristically very down to earth. In Moses' encounter with God in Exodus, God announces that he is 'a compassionate' God, long suffering and abounding in loving kindness.' The word for compassionate, רחום (rahum), is connected with רחם (rehem), a womb, a strikingly feminine and maternal word, but also again very direct and physical. To feel compassion is to be moved deep inside you, in the entrails, in the guts, in the womb. ${ }^{4}$

\footnotetext{
${ }^{2}$ For those interested in the grammar, the Latin verb misereor, 'I pity', normally takes the genitive (as in the famous Psalm 51 [50], Miserere mei, Deus), but sometimes the dative; so both nostri, as in the Vulgate, and nobis, as in the Agnus Dei, are grammatically correct.

${ }^{3}$ misertus, a variant of miseritus, the normal past participle in Classical Latin.

${ }^{4}$ See Nicolas King, 'From the Beginning', The Tablet, 12 December 2015, 10-11.
} 
So going back to our original story of the healing of the blind men in Matthew, the merciful or compassionate act of restoring the men's sight is not just a dispassionate piece of philanthropy or benevolence, of the kind enjoined by a certain kind of utilitarian ethics, but something that flows from a deep visceral response. We are not dealing here with a mere intellectual decision to help, but a much more direct and immediate response in which the whole person is involved. In this context, the 'whole person' implies a biological, embodied being, with physiological responses, as the literally visceral language I've been discussing calls to mind.

But merely pointing to the physiology, valuable though it for warning us off the fallacies of dualism and a bloodless immaterialist account of the mind, does not fully bring out what is involved. After all, physiological events in themselves do not necessarily have moral significance. Your bowels could be churning away, or your stomach clenching, even though you are asleep or anaesthetised, and conversely, you could be deeply moved with compassion, in the sense that Jesus is deeply moved in this story, without necessarily actually manifesting any symptoms in the gut. What this terminology of bowels and womb and so on is gesturing towards, it seems to me, is the importance of the way in which we react to, and perceive the distress of, our fellow creatures. For two very different modes of response are possible. The one mode is abstract, analytical, rational, intellectual - we identity the situation as one involving some harm or suffering that requires alleviation, and we then work out what steps are needed to alleviate it. The other mode, which is implicitly being recommended in these texts, in so far as the way in which Jesus responds is clearly intended as a pattern to be followed, is more immediate, more holistic, more empathetic, more 'touched' - a kind of direct taking in of the distress of the other, and a spontaneous, deeply involved outflowing of compassion and concern.

This notion of a direct and immediate mode of response has been connected with socalled 'right brain' activity in Iain McGilchrist's fascinating book, The Master and His Emissary (2009). There has been a lot of critical reaction to the left-brain/right brain distinction in the recent literature which we need not examine here, since one does not have to take a stand on the details of the brain science in order to see the force of McGilchrist's basic thesis that the world can be apprehended by us in two very different ways. We may, as McGilchrist puts it 'allow things to be present to us in all their embodied particularity, with all ... their interconnectedness'; or we can stand back from the world and see it as 'abstracted and compartmentalised', so as to analyse, assess and control it. ${ }^{5}$

\footnotetext{
${ }^{5}$ Iain McGilchrist, The Master and His Emissary (New Haven: Yale University Press, 2009), 93 (slightly adapted). It should be noted that associating these two modes of awareness with the right and
} 
Here again, as with the bowels and the womb and the gut, it is obviously important that we are embodied creatures, and clearly everything we do and think and feel as moral beings involves circuitry being activated in the brain. But we should avoid being too impressed by the physiological and neurophysiological data, in the way that is becoming common in a certain style of scientifically oriented philosophy. We are all familiar with power-point presentations where the speaker triumphantly points to parts of the brain 'lighting up', as if this shows that there is nothing more to our moral and religious lives that the firing of neurons. The approach is in some ways reminiscent of that of those biological reductionists who appear to think that once you they have conjectured how certain capacities might have helped our primate ancestors survive on the African savannah millions of years ago then they are on the way to explaining everything that needs to be explained about religion or art or literature . Of course parts of the brain 'light up' when you are having a moral or religious experience, or falling in love, or listening to music - how could they not? And of course we couldn't have these experiences without the rich legacy of biological and social responses that have evolved and developed over millennia. But for the meaning of what is going on, and for the nature of what is apprehended, when we listen to music, or poetry, or philosophize, or react morally to other human beings, we need to look elsewhere.

\section{The springs of mercy}

So what is the significance of those deep impulse of love and mercy and compassion that are described in the biblical narratives- impulses that we can all recognize as a part of our human makeup (albeit a fragile and easily displaced part)? No doubt the seeds of such responses are innate in our biological inheritance, but they do not happen automatically - they need to be fostered and nurtured, in the first instance by the mother who is connected in the most direct and intimate way with the infant, and as the child grows, by continuous parental care (which is of course why emotional and moral responses can be so severely damaged when something goes wrong with the parental relationship). And even when the response has been fostered, it can be dulled or stunted by subsequent trauma or by perverted teaching - as occurs in one of the ugliest passages in Western philosophy, in Beyond Good and Evil, where Friedrich Nietzsche urges us to harden our hearts against impulses of compassion in the name of some grand new goal we are supposed to have adopted (creativity, self-realization, the will to

left hemispheres, respectively, is something of a schematic approximation, as McGilchrist himself stresses. There is evidence to suggest that in most people the respective functions do broadly correlate with neural activity in the relevant halves of the brain, but in normal subjects there is constant interaction between the halves. 
power, or whatever other grandiose project takes our fancy). ${ }^{6}$ (Though I think Nietzsche is seriously myopic in failing to discern the significance of compassion, this should not be taken as a refusal to see merit in the rich and original insights to be found elsewhere in his philosophy.)

A similar blind spot, it seems to me, can be found in a much more recent movement in ethics, admittedly rather more benign than Nietzsche's 'revaluation of values', but which still seems to me to risk going badly astray in so far as it recommends abstracting from the direct impulses of mercy and compassion that connect us our fellow humans. I am referring to the latest development in the consequentialist agenda which has been so influential in modern ethics, but which, despite what I am sure are the good intentions of its promoters, such as Peter Singer, seems to me to end up in the wrong place on a whole range of topics (including, for example, the status of animals and the ethics of euthanasia). The particular development I have in mind is the theory of 'targeted altruism' which says that, for instance, being deeply moved by compassion to donate a kidney to a dear friend who has kidney failure is less ethically admirable (because doing far less overall good) than contributing to a charity that distributes mosquito nets to reduce the incidence of malaria. ${ }^{7}$

Suppose you encounter someone in desperate need of help, who begs for mercy like the blind beggars in Matthew. Consider Isabella, in Measure for Measure, pleading for her brother's life to the Deputy Governor, Angelo: 'But show some pity', she begs. He coldly replies 'I show it most of all when I show justice, for then I pity those I do not know. ${ }^{8}$ Angelo refuses to pardon the offender because he says he has the wider welfare to consider; so by ignoring this plea for compassion, by punishing harshly, he claims he is showing compassion to likely future victims through the resulting deterrent effect. By analogy with the theory of 'targeted altruism', we might call this 'targeted compassion'. But it's part of Shakespeare's genius that we, the audience, know, or are beginning to sense, that there is something wrong with Angelo's stern and self-righteous logic; and later in the play, when he falls victim to the very vice he is punishing, he will learn too late that he too can be in need of mercy.

Our lives as ethical beings depend intimately on the immediate responses arising from our interactions and encounters with others in our day-to-day lives. This is part of the point of William Blake's famous observation, 'He who would do good to another must do it in

\footnotetext{
${ }^{6}$ Friedrich Nietzsche, Beyond Good and Evil [Jenseits von Gut und Böse, 1886], §37.

${ }^{7}$ See Thomas Nagel, 'Ways to Help', Times Literary Supplement 20 November 2015, 3-4, reviewing William MacAskill Doing Good Better (Guardian: Faber, 2015), and Peter Singer, The Most Good You Can Do (New Haven, Conn.: Yale University Press, 2015).

${ }^{8}$ William Shakespeare, Measure for Measure (c. 1603), Act II, scene 2.
} 
Minute Particulars: General Good is the plea of the scoundrel, hypocrite \& flatterer. ${ }^{9}$ Of course the way this is put by Blake is a rhetorical exaggeration, in a way grossly unfair to the sincere utilitarian who is rightly concerned about global poverty. But as Dickens brilliantly shows with the philanthropic Mrs Jellyby in Bleak House, who is always attending meetings about missionary work in Africa while blithely ignoring the urgent needs of her own husband and children, there is something important missing in such abstract calculated promotion of the general good. ${ }^{10}$

Mercy is a direct, empathetic response that we cannot do without while still remaining human. The Good Samaritan might possibly have promoted more long-term good by refraining from helping the man on the Jericho road who had fallen among thieves, and instead joining the priest and the Levite who passed by on the other side of the road in order to form a committee to channel resources to alleviate some distant problem of poverty or oppression. But as someone who 'wears a human heart', to borrow David Hume's graphic phrase, ${ }^{11}$ the Samaritan could not but respond to the plight of this victim right there in front of him. And in my view he was right to do so. The visceral response described in the graphic verbs of the Greek New Testament and the Hebrew Bible may be thought of as a way of linking such direct receptivity to others with our inner awareness of our own vulnerability, when we feel 'churned up', as we say - when our guts are twisted, and we know we are not angelic disembodied minds, or moral calculating machines, but fragile, mortal creatures of flesh and blood.

At the very roots of the moral impulse, I would argue, is that capacity for openness, for 'porousness', as Martha Nussbaum calls it, ${ }^{12}$ where we lay aside our faculty for detached, analytic, judicious assessment in favour of the powerfully urgent feeling that, as Philippa Foot once put it, 'we are all in the same boat' (the fundamental sense that she accused Nietzsche of lacking). ${ }^{13}$ In perhaps the most famous reference to mercy in English literature, in the Merchant of Venice, Portia describes the quality of mercy as a free gift that drops as the gentle rain from heaven, without being exacted or constrained, without being 'strained', as she puts it. But the most significant part of the speech is perhaps some lines that come later: 'We do pray for mercy, and that same prayer doth teach us all to render/the deeds of mercy. ${ }^{14}$ Mercy is not to be measured and weighed out, it cannot answer Shylock's demand

\footnotetext{
${ }^{9}$ William Blake, Jerusalem (1805), ch. 3.

${ }^{10}$ Charles Dickens, Bleak House (1853), Ch. 4: 'Telescopic Philanthropy'.

${ }^{11}$ David Hume, Enquiry concerning the Principles of Morals (1751), Section V, part 2.

${ }^{12}$ Martha Nussbaum, Love's Knowledge (Oxford: Oxford University Press, 1990), 282.

${ }^{13}$ Philippa Foot, 'Nietzsche's Immoralism', In R. Schacht (ed.) Nietzsche, Genealogy, Morality (Berkeley, CA: University of California Press, 1994).

${ }^{14}$ Shakespeare, The Merchant of Venice (1605), Act IV, scene 1.
} 
'on what compulsion must I [be merciful]?', but arises out of an openness and sensitivity to the distress of others that wells up inside us, bringing with it a vivid awareness that we too are in deep need of compassion.

\section{Merely human or something more?}

What I have said so far, about the rationale for mercy being rooted in the awareness we have of our own needs and our vulnerability, may suggest that its ethical rationale can be explained in entirely human or secular terms. But Simone Weil casts serious doubt on this when in a remarkable passage she observes 'Those who have the privilege of mystical contemplation, having experienced the mercy of God, suppose that the created world is a work of mercy. But as for obtaining evidence of this mercy directly from nature, it would be necessary to become blind, deaf and without pity in order to believe such a thing possible., ${ }^{15}$

Part of what Weil may mean here is that when we look at the universe around us cataclysmic explosions, colliding galaxies, dying stars, or, on planet earth, tsunamis, plagues, earthquakes, it seems absurd to talk of grounding the requirement to be merciful in the way the world actually is. And this includes the way human nature is. For it seems very doubtful that an appeal to our biologically and culturally evolved nature can generate the right kind of what today's philosophers call normativity. In other words the question is whether human nature can imbue the value of loving kindness and mercy with the requisite moral authority to serve as an overriding principle of action. It is certainly true, as Hume pointed out, that feelings of benevolence and compassion are a natural part of our human makeup, but it is unfortunately also true that selfish and aggressive feelings are equally prevalent: as Hume himself piquantly acknowledged, 'a particle of the dove is kneaded into our frame along with elements of the wolf and serpent., ${ }^{16}$ And that being so, there seems no compelling reason why one particular affectionate strand in our complex and diverse array of natural inclinations should have supreme normative force in our lives. As Bernard Williams graphically put it, our human nature is a 'rather ill-sorted bricolage of powers and instincts ${ }^{\prime}{ }^{17}$ and in this contingently evolved aggregate of traits and characteristics there seems nothing to entitle one particular set of instincts or desires to take normative precedence over the others.

\footnotetext{
${ }^{15}$ Simone Weil, 'He whom we must love is absent' [c. 1941] in G. Thibon (ed) La Pésanteur et La Grace (Paris: Plon, 1947), trans. M. von der Ruhr as Gravity and Grace (London: Routledge, 2002), 110.

${ }^{16}$ Hume, Enquiry concerning the Principles of Morals, section IX, Part 1.

${ }^{17}$ Bernard Williams, 'Replies,' in J. Altham and R. Harrison (ed.), World, Mind, and Ethics (Cambridge: Cambridge University Press, 1995), 199.
} 
If our evolved nature cannot do the job, nor, I think, can Kantian rationality. Immanuel Kant famously proposed that to assess the permissibility of my conduct I should ask if it accords with a maxim that could be willed as a universal law. ${ }^{18}$ So I cannot rationally will that I should myself be loved and cared for when in need unless I am prepared to assent to the maxim that everyone (including, of course, myself) should love and care for those in need. The problem with this approach, as has been various explored by subsequent critics, is that there seems no contradiction, whether conceptually or in the will, in someone's refusing to allow that the need or suffering of others is a reason to reach out to them in love and compassion. There is no incoherence in the attitude of the egoist who simply rates his own plans and projects as of supreme importance, ignores the needs of others, and is quite prepared to accept the consequences were everyone to act likewise. Going back to Nietzsche's rejection of the Christian ethics of love and compassion, and his advocacy of a willingness to 'let people suffer', as he put it, ${ }^{19}$ perhaps this displays a curious kind of moral myopia, but it does not appear to violate any principles of practical or abstract rationality.

The Judaeo-Christian take on these matters is very different from anything found in philosophical theories of ethics, whether Humean or Kantian. ${ }^{20}$ In the Hebrew Bible, there are many instructions and regulations for conduct issued to the Israelites, but there are two particularly striking commands to love: 'you shall love the LORD your God with all your heart and with all your soul and with all your strength' (Deuteronomy 6:5); and 'you shall love your neighbour as yourself' (Leviticus 19:18). These two texts are reflected in many of the subsequent teachings of the Old Testament and inform many episodes in the New Testament, like those I mentioned at the start of the paper, as well as in the explicit teachings of Jesus, who describes the command to love God as 'the first and greatest commandment', and declares that upon this and the second commandment to love your neighbour (which is 'like the former') hang 'all the law and the prophets' (Matthew 22:37-40).

The idea that we can be commanded to love has often been seen as problematic. Immanuel Kant famously underlined the principle that 'ought implies can', and is widely regarded as holding that love cannot be a duty, since one cannot love someone at will - one either feels love or one does not. But there is a distinction Kant makes in the Groundwork between 'pathological love' (an emotion that arises rom pleasure caused by the other) and 'practical love' (a desire to benefit them based on duty). And Kant explicitly states that 'love

\footnotetext{
${ }^{18}$ Immanuel Kant, Groundwork of the Metaphysic of Morals [Grundlegung zur Metaphysik der Sitten, 1785], Ch. 2, §25.

${ }^{19}$ Cf. Friedrich Nietzsche, Beyond Good and Evil, $\$ 202$.

${ }^{20}$ In this and the following section I take up some of the points made in my 'Love and Religion', in C. Grau and A. Smuts (eds), The Oxford Handbook of Philosophy of Love (Oxford: Oxford University Press, 2017), Ch. 35.
} 
as an inclination cannot be commanded; but kindness done out of duty, even though an ... aversion stands in our way, is practical love, not pathological love. It resides in the will, and not in the partiality of feeling. ${ }^{, 21}$ So for Kant there is a duty of kindness and beneficence to our fellow humans, this being something that is clearly within our power, whereas there is no requirement to like them or to be fond of them, since this may be beyond our power, no matter how hard we try.

Construing the command to love one's neighbour in this relatively prosaic way, as a duty of beneficence rather than a requirement to respond with warmth and affection might seem to fit in with the tone of some of the other biblical teachings about the relationship to one's neighbour. It we go back to the command in Leviticus to love one's neighbour, the context in which this occurs is a list of instructions that are concerned with not doing harm, or, more positively, with showing some consideration to others, rather than what would normally be called love. Those cultivating the land are told not to reap to the very edges of the field or to harvest every last grape from their vineyards, but to leave some over for the benefit of strangers and those in need. Yet even this is not merely a matter of detached or impersonal benevolence, but implies a kind of emotional identification with those in need: 'you shall love the stranger as yourself, for you were strangers in Egypt' (Leviticus 19:31). And when we come to teachings of the prophets it becomes even clearer that the idea of loving one's neighbour is taken to involve much more than merely treating others decently. Isaiah tells his listeners to share their bread with the hungry, clothe the naked, and even take the poor into their own homes (Isaiah 59:7). In similar vein, the Book of Proverbs insists that even our enemies must be fed and given water if they are hungry or thirsty (Proverbs 25:21). The teachings of Jesus are very much of a piece with this more exacting interpretation of the love commandment. The Sermon on the Mount famously tells us to love our enemies (Matthew 5:44); and in the fearfully graphic description of the Second Coming, the message is that our whole lives will be judged on the basis of whether we have fed the hungry, clothed the naked, and visited the sick and those in prison (Matthew 25: 34-6). In short, the conception of love that progressively emerges in this Judaeo-Christian tradition involves far more than the mere discharge of a duty: it implies a pervasive mindset of caring and compassion towards all with whom one comes into contact.

The special moral significance accorded to neighbour-love in these and other scriptural passages can only fully be appreciated by placing the requirement to love one's neighbour alongside the first of the 'great commandments', the command to love God

\footnotetext{
${ }^{21}$ Immanuel Kant, Groundwork for the Metaphysic of Morals [Grundlegung zur Metaphysik der Sitten, 1785], Ch. I, §10, trans. T. E. Hill and A. Zweig (Oxford: Oxford University Press, 2002) 201.
} 
(Deuteronomy 6:5). The intensifiers that are used in the Deuteronomy text - 'with all your heart and soul and strength' - imply far more than a duty of obedience, suggesting instead a passionate and fervent devotion. The idea of a requirement to love God in this way is absolutely unique to the Jewish religious outlook (and its Christian offshoot) - there is, so far as I know, nothing remotely like it in any of the world's other religions. It is no mere ethical precept, but is more like a call to enter into a powerful and demanding relationship that will infuse every aspect of life. The declaration of Jesus that the second commandment (to love one's neighbour) is like the first (Matthew 22:39) may well be best understood in this light. Since human beings are made in the image of God (Genesis 1:27), each human being has a special dignity and worth, and is owed something of the respect and love that is due to God. So failure to love our neighbour is, in a certain way, a failure to love and respect God. As Simon May has expressed it in his richly insightful book on love:

The point of loving your neighbour as yourself is ... in the final analysis, not to create a more cohesive and efficient society, or to maximise happiness and contentment. It is simply to do as God does out of love for God, in whose image we - you and I and our neighbour in equal measure - are made. Love. we see here, has ethical force as a relation to the source of our being. ${ }^{22}$

Evidently we are no longer dealing here with a mere prescription for intermittent charitable action. Something much greater is at stake, something that relates to the very meaning of human life and to our status as dependent creatures. The requirement to love one's neighbour as oneself implies a recognition of the dependency we all share, and the linkage of love of neighbour to love of the creator transforms a duty of beneficence into something of cosmic significance.

\section{The cosmic significance of love}

My argument so far suggests that it will be far from easy to preserve in purely secular terms, the special authority and resonance of the love commandment as it has come down to us in the Judaeo-Christian tradition, a resonance that connects with what one might call the 'cosmic' significance of love.

In the first Epistle of John, love is identified with God: 'whoever does not love does not know God, because God is love' (I John 4:8). And again, a few verses later: 'God is love, and whoever lives in love lives in God and God in them' (4:16). Love does not of course

\footnotetext{
${ }^{22}$ Simon May, Love: A History (New Haven, CT: Yale University Press, 2011), p. 18.
} 
exhaust the nature of God on the theistic worldview, since many other characteristics are ascribed to God in the Scriptures, including justice and righteousness. And in the Gospel of John, what is famously underlined in the first chapter is logos - word, intelligence, rationality. So the resulting conception of the cosmos to which we belong is that of a rational and a moral cosmos - one in which human beings can feel fundamentally at home, provided they live their lives in conformity with reason and love, logos and agapē.

But the primacy of love remains inescapable in the vision of a good human life that emerges from this conception. We are not just required to live 'in accordance with nature', or 'in accordance with reason', as the Stoic philosophers advocated, ${ }^{23}$ but to 'abide in love' (I John 15:9). In the theistic picture as it is developed in Judaism and Christianity, our very existence is a free gift bestowed by the creator, a creator of loving kindness and compassion. The life of love to which we are called reflects our complete dependence on God, the loving creator who first gave us existence, and this is a theme to which the reflections in the first letter of John often return: 'this is love, not that we loved God, but that he loved us' (I John 4:10); and again, 'we love, because he first loved us' (4:19). (One should perhaps add that in Islam too, one of the names by which God is known is al-Wadud, He who loves; and of course each verse in the Qu'ran starts with an invocation to God as al-Rahman and al-Rahim the all-Compassionate, the all-Merciful.)

The worldview in which love plays such a central role has seemed to many people to have become increasingly difficult to hold on to, in the light of the shifts in our understanding of the world produced by the scientific revolution. Dante was able to speak confidently and unhesitatingly of 'the love that moves the sun and the other stars', 24 taking it as read that the force that powers the universe is identical with love as conceived of in Christian theism. But modern science presents us with a cosmos whose workings are to be understood in entirely abstract and impersonal terms (through mathematics and mechanics); and even when we move from physics to biology, the received account of how life developed on our planet appears to replace cosmic providence or benevolence with the notions of chance mutation and a blind and brutal struggle for survival.

A kind of existential malaise is all too apparent in many nineteenth and twentieth century writers struggling to come to terms with this fundamental shift in our understanding of the nature of the cosmos and our human place within it. There could hardly be a sharper contrast between Dante's confidence in the 'love that moves the sun and other stars' and the

\footnotetext{
${ }^{23}$ For these Stoic formulations, see A. Long and D. Sedley, The Hellenistic Philosophers (Cambridge: Cambridge University Press, 1987), §§63A and B.

${ }^{24}$ Dante Alighieri, The Divine Comedy: Paradise [La Divina Comedia: Paradiso c. 1310], final line.
} 
poet A. E. Housman's anguish at being being 'a stranger and afraid/ In a world I never made'. ${ }^{25}$ To be able to believe that there is love at the heart of reality supports a sense of being 'at home' in the world, the sense Wittgenstein described when he characterised the religious outlook as involving a feeling of 'absolute safety'. ${ }^{26}$ In Tennyson's In Memoriam, where the poet has found his faith sorely tested, in one of the verses that begins 'Love is and was my Lord and King', he is still able to express this feeling of security in a way which perhaps we can only look back on now with melancholy nostalgia:

I hear at times a sentinel

Who moves about from place to place,

And whispers to the worlds of space,

In the deep night, that all is well. ${ }^{27}$

This intimation of a loving power at the centre of things provides a sense of what Simon May has aptly called 'ontological rootedness', ${ }^{28}$ and for those for whom love can no longer be seen as the ground of our being - the ontological source of our existence and that of the very universe - the basis for such a sense of rootedness crumbles away.

It is a striking, though perhaps in a way depressing, feature of our contemporary culture that purely human love is frequently presented in a way that seemingly offers to fill the resulting void. Phrases such as 'you're all I'll ever want', 'you're my reason for living' are to be found in the lyrics of countless pop songs, where the implicit assumption appears to be that a certain kind of romantic love can somehow underwrite the whole meaning and purpose of our lives. It is of course true that genuine love (in contrast to the debased Hollywood fantasy of 'love at first sight') can be a powerful long-term source of meaning and value in peoples' lives; but the slogan found in the Beatles' song, 'All you need is love', if taken to refer to romantic attachments, is evidently absurd. Not only is the continued flourishing of a loving relationship necessarily subject to the contingencies and fragilities that beset all human life from birth to death, but there is something fundamentally unfair, and perhaps infantile, about loading onto another human being, however noble and worthy of affection, the entire weight of being the sole source of life's meaning and value.

\footnotetext{
${ }^{25}$ A. E. Housman, 'The laws of God, the laws of Man', in Last Poems [1922], repr. in Collected Poems (Harmondsworth: Penguin, 1956).

${ }^{26}$ Ludwig Wittgenstein, 'A Lecture on Ethics' [1929], in Philosophical Review (1965), 8.

${ }^{27}$ Alfred Tennyson, In Memoriam (1849), CXXVI.

${ }^{28}$ May, Love, 6-7.
} 
So how do we address the classic modern predicament of a loss of rootedness? In recent times, many Western philosophers have been drawn to the quite different take on these matters that is provided by some of the Eastern religious traditions, notably Buddhism, so it may be worth concluding with a very brief comment on this. For the Buddhist, ultimate reality is not personal at all: there is no God, and indeed even for the ordinary human being the very notion that he or she has an enduring 'self' is an illusion. There are simply conditions that arise and pass away, and enlightenment consists in freeing oneself from the desires and attachments that lead us to try in vain to cling on to what is ephemeral.

It is interesting to find that that despite this metaphysical background (so different from the intense theistic emphasis on the personal), love and compassion still play a central role in the Eastern conception of the spiritually enlightened life. But it is not the love of commitment and attachment, or of devotion to a personal creator, but rather a boundless feeling of compassion stemming from pity for the suffering of those in the grip of desire and illusion. Thus the atheist philosopher Sam Harris, speaks of the spiritual exercises of meditation in this tradition as leading to 'boundless love', 'selfless wellbeing', and 'selftranscendence'. ${ }^{29}$ Similarly, the French atheist philosopher André Comte-Sponville, also attracted by 'oceanic' feelings of self-transcendence, ${ }^{30}$ speaks of ideal love or charity as a kind of letting be. The one who 'forbears' is the diametric opposite of the self-absorbed egoist who tries to fill all the available space:

This kind of love is the rarest of loves, the most precious and miraculous. You take a step back? He takes two steps back. Why? Simply to give you more room, to avoid crowding you, invading you, or crushing you, to give you more space and freedom and to let you breathe ... He steps back so as not to impose on you his power, or even his joy or love, so as not to take up all available space, all available being, or all available power. ${ }^{31}$

The oceanic vision is not of a love that is supposed to 'ground' us, or bring us into union with the creative source of our being and selfhood, but rather a love that arises from the dissolving of personal craving, where reality is conceived of as a constant flow of impersonal conditions that come into being and pass away. Theists will be unable to accept this impersonalist vision of ultimate reality, but there are clearly problems in the idea that

\footnotetext{
${ }^{29}$ Sam Harris, Waking Up: A Guide to Spirituality without Religion (London: Bantam Press, 2014), $14,17,18$.

${ }^{30}$ André Comte-Sponville, The Book of Atheist Spirituality [L'esprit de l'athéisme, 2006] (London: Bantam, 2008), 150ff.

${ }^{31}$ André Comte-Sponville, A Short Treatise of the Great Virtues [Petit Traité des Grandes Vertus, 1996], (London: Heinemann, 2002), 276.
} 
philosophical argument can serve as a way of adjudicating this difference of vision. Here I would be disposed to agree with Richard Rorty, and indeed Wittgenstein in his later work: the whole idea of the philosopher as an abstract metaphysical adjudicator is untenable, since philosophical understanding can only operate from within a form of life, or from within a cultural tradition (though this should not rule out continuous critical scrutiny as we go along). ${ }^{32}$

But this need not lead to a relativistic free-for-all. There are reasons, there is evidence, for the adoption of a particular world view, but (as I have argued elsewhere) ${ }^{33}$ it is not 'spectator evidence' - not evidence of the kind that is accessible to any rational and impartial observer. ${ }^{34}$ In our deep responses of mercy, in our intuitive acknowledgement of the normative requirement to love our fellow humans - however much we may fall short, and however defiantly we may try to turn in the other direction - we sense something beyond ourselves that commands our allegiance whether we like it or not (unless of course, we manage, to find a way of deflating these responses, as mere illusions). So our picture of the cosmos, or of ultimate reality, if it is to be a vision we can embrace with integrity, must be such as to support those intuitions. And the considerations offered in this paper perhaps go a little way to suggesting that only something like a theistic picture may have the wherewithal to do full justice to them. This, in the end, is what it means to say that loving kindness and mercy have a cosmic, a more than merely human, dimension. To embrace theism, on my view, is not suddenly to be able to provide a rational or quasi-scientific explanation of this cosmic dimension; but it is to be able to trust that the vision is valid; and at the practical level it is to be prepared to be receptive, to align oneself with a tradition of spiritual praxis which offers some hope of incorporating that vision into our lives.

JOHN COTTINGHAM (jgcottingham@mac.com) is Professor of Philosophy of Religion at the University of Roehampton, London, and Professor Emeritus of Philosophy at the University of Reading. His recent books include Philosophy of Religion: Towards a More Humane Approach (Cambridge University Press, 2014), and How to Believe (Bloomsbury, 2015).

\footnotetext{
${ }^{32}$ Richard Rorty, Philosophy and the Mirror of Nature (Oxford: Blackwell, 1980), Ch. 8; Ludwig Wittgenstein, Philosophical Investigations [Philosophische Untersuchungen, 1953], transl. G. E. M. Anscombe (New York: Macmillan, 1958), §23.

${ }^{33}$ John Cottingham, Philosophy of Religion: Towards a More Humane Approach (Cambridge: Cambridge University Press, 2014).

${ }^{34}$ See Paul Moser, The Elusive God: Reorienting Religious Epistemology (Cambridge: Cambridge University Press, 2008), 47.
} 